\title{
Perforated Democracy: Disintegration, State-building, Europeanisation and the Erased of Slovenia
}

\author{
Damjan MANDELC, Tjaša UČAKAR \\ Department of Sociology, Faculty of Arts, University of Ljubljana, Slovenia \\ damjan.mandelc@guest.arnes.si,tjasa_ucakar@yahoo.co.uk
}

\begin{abstract}
This article explores the process of disintegration of Yugoslavia, the state-building process in Slovenia and the context of the specific phenomenon - the erasure that took place in Slovenia in the early 1990s. It reconstructs the socio-historic and political contexts in which the independence of Slovenia occurred. While describing the state-building process, the process of democratisation and the dilemmas about minority protection in Slovenia - including the distinction between the recognised "autochthonous" minorities and the non-recognised "new" minorities - it paves the ground for theoretical and sociological discussion of the "erased". The theoretical discussion is based on the questions of human rights, nationalism and citizenship, both in its classic (nation-state) conception and its alternative forms such as global citizenship. Sociologically, it places the "erasure" into a broader frame of investigating the processes of democratisation and Europeanisation, thus highlighting the key factors that caused the perforation of Slovene democracy in its twenty years of independence.
\end{abstract}

Key words: state disintegration, state-building, Europeanisation, the erased of Slovenia, democratisation, human rights, citizenship

\section{Introduction}

With the notion of "perforated democracy" we want to point to the holes in democracy, thus, the areas where democracy is leaking, where there is a deficiency in democracy." The most sensitive time, when democracy is facing a challenge of shortcomings, is the transition between different political and social regimes, during a time of rapid socioeconomic change and

\footnotetext{
* This paper is the result of the research project "The Challenges of Europeanisation: Mediating between National and European Identities in South Eastern Europe" (SEUM, 2010-2011), which has been carried out with the support of the ASO (Austrian Science and Research Liaison Office), Ljubljana (www.seumproject.eu).
} 
political, religious, and cultural ferment (Alvis, 2005; Lockard, 2008). In its rather short history as an independent state, Slovenia went through many such challenging processes, namely the disintegration of the former Yugoslavia, with achieved independence in 1991, the state-building in the early 1990s, and the Europeanisation that culminated in 2004 with the joining of the European Union. The democratisation of Slovenia was widely perceived as non-problematic; in the broader transnational political arena the country's move towards independence was even used as a model, since it did not lead to similar wars as elsewhere in the collapsing Yugoslav region. But for a large group of people, Slovenian independence was not a success story. To the contrary, close to 25,000 people who were "erased" from the permanent residents register experienced the move toward democracy as a total deprivation of their human rights. In our analysis, we provide a sociological reflection of the processes of disintegration of Yugoslavia and the subsequent state-building and Europeanisation of Slovenian society. We use this reflection as the explanatory frame to trace the very act of the erasure; and the ideological contexts that turned a brief administrative "mistake" into a long and devastating agony for the erased - and for democracy in post-Yugoslav Slovenia. This has been done on the basis of putting together various primary and secondary sources, which are reconstructed with the socio-historical method to provide a sociological narrative of the "perforated democracy".

\section{Disintegration of Yugoslavia and state-building in Slovenia}

At the dawn of establishment of socialist Yugoslavia, people of different nations came together to form a stronger, multinational political unit, which was seen to bring more benefits than smaller weak states trying to recover from the experience of the Second World War. Four decades later, following the death of Josip Broz Tito in 1980, Yugoslavia encountered numerous social, economical, political, ethnic and other problems, accompanied by the new geopolitical uncertainties. In 1989, radical political changes occurred in Eastern Europe, associated with the liberalisation of the authoritarian regimes and systems, and with the erosion of political power in all the so-called Warsaw Pact countries. According to official sources, hundreds of enterprises declared bankrupcy, and more than half a million people lost their jobs in Yugoslavia in 1989 alone. The atmosphere of social despair and hopelessness was widespread. It was clear that Yugoslavia as a state could not overcome these problems without a serious transformation of its political and economic system. Several ideas of how to overcome the emerging crises were put forward, including decentralisation, introduction 
of a multiparty system and free elections; the communist (and nationalist) core of Serbian leadership, backed by the high ranks of the Yugoslav People's Army, rejected the suggestions for an alternative development, trying to preserve the status quo. This led into the federal republics' attempts to gain independence, where Slovenia was followed by the Croatian, Macedonian and Bosnian response. When the first democratic elections were held in Slovenia in April 1990, the Yugoslav leadership, instead of continuing the dialogue, decided to use armed force to prevent the processes of democratisation and disintegration of the federal state (Ramet, 1996; Glenny, 1996; Bebler, 2010). ${ }^{1}$

Yugoslavia, being a multinational state, was witnessing tensions between twofold loyalties, loyalty to a federal state on the one hand and one's own national community on the other. Keeping the balance between the two was one of the most challenging tasks in Yugoslavia - a task that central authorities could not handle. As we read in Matić (2006: 267), communism determined the identity of Yugoslavia, according to which the loyalty to the state equalled loyalty to communist ideology. ${ }^{2}$ However, the communist idea started to lose its appeal throughout the years. National (communist) elites could not find a common language on how to resolve the crisis; during the turbulence of the late 1980s and early 1990s, the shift from Yugoslav (transnational, unitary, socialist ideology and identity) towards (ethno)nationalistic sentiments took place.

Processes of democratisation in Slovenia were largely accompanied by the process of re-nationalisation - Slovenia followed the "ethnic" model of state-building. Despite emerging democratic structures, (certain) minority groups in the newly formed state were being exposed to discrimination. One can prove such discrimination on several cases; while Italian and Hungarian minorities were widely financed and supported by the state, some other groups were not as generously awarded. ${ }^{3}$ Giving a proper civic status

\footnotetext{
${ }^{1}$ For detailed information on the disintegration of federal Yugoslavia, and political processes from the death of President Tito to interethnic wars, see also: Janjić, 1992; FinkHafner, 1995.

${ }^{2}$ Walker Connor writes that to maintain the multinational states one must keep the balance between the two types of loyalty, loyalty to the nation and loyalty to the state - so in a situation when these two loyalties come into conflict, loyalty to the state loses the battle (Connor, 1994: 81).

${ }^{3}$ For instance, the unofficial Muslim minority (predominatly of Bosnian origin) has been waiting for almost four decades to being allowed by state authorities to build its first mosque in Slovenia. As the same time, the Serbian ethnic/religious minority (again unofficial) was waiting for more then two decades to obtain permission to build the Orthodox cultural centre in the capital of Slovenia. Not to mention the obstacles for Roma com-
} 
to the autochthonous "old" minorities, Slovenia forgot about other groups, specifically those belonging to other Yugoslav republics. The implied assumption was that granting protection to the existing legally recognised minorities would block any possible ethnic conflicts in the future, while human rights would be observed.

Therefore, when speaking of minority issues, the political and legal discourse focused only on the pre-existing minorities, called "old", indigenous, and also "autochthonous". ${ }_{4}^{4}$ As Rizman reminds us, "the Council of Europe's Commissioner for Human Rights, Álvaro Gil-Robles during his visit in 2003 already suggested to the Slovene government to get rid of distinction between autochthonous and non-autochthonous national minorities. [...] it can still be said that all Slovenian governments ignored the issue and just mentioned advice" (Rizman, 2006: 129).

Article 5 of the Constitution specifically names solely the Italian and Hungarian minorities as protected national minorities. Only once in the Constitution is the word "minorities" (manjšine) used and it is in specific reference to the autochthonous minorities. Not once does the Constitution mention the protection of any other minorities, such as minorities from the former republics of Yugoslavia. Article 64 of the Constitution protects the right of autochthonous minorities to use national symbols and keep national identity cards; it grants them the right to education and schooling in their own languages. These rights are not guaranteed to the new minorities; legally invisible, the new minorities therefore do not exist in the political vocabulary or in state institutions. However, as we will see below, they do have a place in the national imaginary where they play an ambiguous role as the (un)wanted residue from Yugoslav history.

Discrimination as a form of ethnocentrism was prevalent throughout the history of independent Slovenia. The presence of inhabitants and workers from other former Yugoslav republics, who were perceived as remainders of the common Yugoslav history, was seen as an instrument of "Yugoslavisation" of Slovenia, which wanted to distance itself as much as possible from its Balkan neighbourhood, and "returned home, to the company of

munities, whose minority status was excluded from the Slovene Constitution, (providing only the status of an ethnic community), and while the Constitution required the "umbrella law" on the Roma ethnic community, such law has been adopted only in March 2007. To see more on the situation of the Roma community see http:/www.uvn.gov.si/en/minorities/ roma_community/.

${ }^{4}$ Due to its arbitrary nature, the term "autochthonous" is no longer used in EU documents in regard to national and ethnic minorities. In this sense, Slovenia is an exception (Kralj, 2009: 2). 
western European nations, to where it has always belonged, by virtue of culture, history and civilization" (Petrović, 2009: 10). All traces of former shared Yugoslav history thus needed to be removed from the society for it to make the transition successfully into a modern European national state. Europeanisation was thus seen as separation from the Yugoslav legacy, and not as a possible result of democratisation.

In his article on nations, identity, and conflict, Jonathan Glover writes that "nationality is often thought of as something 'natural' or presocial [...] naturalness is reinforced by stories nations often have about their own antiquity. But some historians and social scientists emphasize the relative modernity of the European nation-states, dating them from around the end of the eighteenth century" (Glover, 1997: 12). We see a replica of this $19^{\text {th }}$ century model reiterated in Slovenia of the late $20^{\text {th }}$ century. Driven by the collective enthusiasm of forming an independent state, the national elites in Slovenia exaggerated the need for homogeneity. The discourse they employed stressed the need to disassociate society culturally and historically from its recent, post-World War II socialist past and embark on a path of development, which would eradicate traces of multicultural and multiethnic formula of collective identity building. The immigrants from former Yugoslavia, being a historical reminder of the past of which Slovenia was once consensually a part, begun to play the convenient role of the ethnic "fifth column" (Kymlicka, 2007) within the emerging independent national society. With its presence, the immigrant subject from the former Yugoslavia of multiethnic and transcultural and transborder "brotherhood and unity" destabilised the certainty of the nationalist discourse, which claimed that ethnocultural homogeneity can be the only proper base of national loyalty. To grant this subject legal protection would not only mean granting him public visibility but, at the symbolic level, also an acceptance of Yugoslav history as a factor in the identity-building of the hegemonic Slovenian national subject. Therefore, obliteration of the fact of the existence of the immigrants and the need for their legal protection as minorities conveniently served several purposes at once. Of these, the symbolic neglect of their legal group status may not have been the most violent one in terms of their political representations; but it most certainly was the most forceful in terms of public legitimation of their exclusion from the bonds of the national society.

When Anthony D. Smith was making observations on Yugoslavia in 1981 he noticed how Slovenia (and Croatia) enjoyed "higher living stand-

\footnotetext{
${ }^{5}$ Here, good references for further reading are also Anderson (1995) and Gellner (1983).
} 
ards than a preponderantly agricultural, and rather backward, Serb core area. And yet, Slovene and especially Croat discontent and desire for greater autonomy, even in federal Yugoslavia, remain powerful political forces. Ethnic groups in economically advantaged regions [...] are just as susceptible to violent ethnic protest movements as those which inhabit backward areas" (Smith, 1981: 29). With Smith, we can argue that aggressive nationalism in economically advanced states is no less a potent tool of mobilisation of social fears than is the case in underdeveloped countries. In fact, Slovene political elites skilfully employed popular perceptions of the continuing economic exhausting of vital economic powers of the North by the South in post-Tito Yugoslavia. Whereas this is not the place to discuss how the uneven development in Yugoslavia was an actual source for the national political and economic elites in maintaining their position of power, it is important to link this ideological sentiment with the stigmatisation of the immigrants as the prolongation of this past practice of exhaustion within the now independent, post-Yugoslav state.

To sum up, the process of democratisation and state-building in Slovenia was perceived by the international community as an exemplary model of transition into the new social and political order. However, while the commitments to form a democratic state, based on the protection of human rights, and the accepted legislation, were publicly and legally articulated, the reality in many regards was far from the declared model. Daniele Conversi writes that "[a]ny process of nation-building insensitive to ethnic nuances and local subjectivities implies a parallel process of nation-destroying among minority groups" (2003: 3). This statement can be used to describe the process in Slovenia, namely the process of state building based on parallel construction and destruction of legacies, which could make the immigrant minorities a legitimate and autonomous (civic) national subject. While Slovenian political elites turned to pre-World War I history to revive the allegedly true and authentic ethnic substance of the nation, they blatantly omitted the cultural traces of collective identity, which could be considered as Yugoslav. As we show next, it was within this context that the "erasure" could and did take place. We also argue that it is only by considering this wider political and ideological context of transition "towards democracy" that the collapse of the basic democratic mechanisms of protection of the legal state, and the violation of human rights can be explained.

\section{The erased of Slovenia}

The erased of Slovenia are a group of about 25,000 people, who were erased from the Registry of Permanent Residents of Slovenia in 1992. They 
were citizens of other former republics of Yugoslavia, who had a registered permanent residence in Slovenia but did not acquire the citizenship of the Republic of Slovenia after its proclamation of independence. Thus, on 26 February 1992 they were transferred to the jurisdiction of the Aliens Act, which led into deprivation of their former permanent resident status. They became foreigners, illegally living in Slovenia. In this way, they were left without political, economic and social rights. Slovenian authorities did inform residents that were not automatically moved to the newly formed civic body and that they must apply for the new Slovenian citizenship if they wished to acquire it. However, the authorities did not inform the residents that failure to obtain Slovenian citizenship would also result in the cancellation of permanent residence. In fact, the Aliens Act did not foresee a similar consequence, but since it did not provide either for the transitory status of the former Yugoslav nationals or for the automatic acquisition of alien status, the Ministry of Interior solved the legal gap by a decree stating that the records concerned should be transferred from the Permanent Residents Register to the Aliens Register.

When analysing the erasure phenomenon, the question that arises is how did the erasure occur and, more importantly, why was it possible? One would argue that the legal gap in the Aliens Act made the erasure possible. Since that gap had to be solved, the Ministry of Interior adopted a discriminatory decree. But the complexity of the erasure phenomenon can not be satisfactorily explained solely from a legal point of view.

The social atmosphere during the independence process was instrumental in the occurrence of the erasure. The newly established state, as demonstrated above, wanted to distinguish itself from its Balkan vicinity as obviously as possible, which affected the process of formation of new Slovenian citizenship. In order to achieve national homogeneity, the newly established state nationalised the right to citizenship and thus put all ethnically non-Slovene residents in an inferior position. In this context, the erased were easily labelled as the cultural Other, as unsuitable members of the new state. Their non-acquisition of Slovenian citizenship was understood as their lack of faith in the newly formed state; they were therefore labelled as traitors, aggressors and opponents of Slovenia. They remained representatives of the Balkans, from which Slovenia wanted to distinguish itself as radically as possible; therefore an explicit racist discourse emerged in order to separate us from them. As Vlasta Jalušič observes, various social spheres ideologically contributed to formation and conservation of the racist discourse with their indifference to discriminations. Although numerous officials encountered many erased persons, they 
merely followed the discriminatory rules instead of notifying their superiors about the illegalities (Jalušič, 2007). Moreover, prior to erasure, the erased had had their friends, acquaintances, neighbours and colleagues in Slovenia who largely became indifferent to the discriminations after the erasure and thus maintained the erased in their illegal status. Furthermore, the silence of the media played a significant role in keeping the erased in their marginal position (Lipovec Čebron, 2007). The society's prevailing perception was that the erasure was a consequence of the normal functioning of the state, not its deviation, and especially that it was not caused intentionally and systematically. Vlasta Jalušič names this phenomenon organised innocence, which emerged as an attempt to avoid responsibility and to make it collective (Jalušič, 2003).

It was only in 1999 that the unconstitutional nature of the erasure was legally recognised by the Constitutional Court, which confirmed its judgment in further court decisions. In its last judgment about the erasure, in 2003, the Constitutional Court ordered the ministry to issue supplementary decisions for those erased that had by that time managed to obtain legal status on establishing their permanent residence in Slovenia as of 26 February 1992. It was only with the re-election of the centre-left government in 2008 that the Constitutional Court judgment from 2003 was implemented. For the erased who had already obtained their legal status, the Ministry of the Interior issued supplementary decisions, establishing their permanent residence in Slovenia as of 26 February 1992. For the others, the ministry adopted a special act, which presents an opportunity for most of the erased to regain their permanent resident status. The adopted act is completely in line with the Constitutional Court's decision but, therefore, some groups of erased persons have been left out. The act is based on individual treatment and it expects the erased to initiate proceedings, even though they themselves were not responsible for the erasure. Furthermore, the act does not regulate the indemnity questions nor does it assign the responsibility for the erasure (Kogovšek, 2007; Izbrisani..., 2010).

\section{The erasure as a representative study of some key theore- tical concepts}

Although the case of the erasure is not directly linked to the question of citizenship, it raises important questions related to nationalism, human rights, citizenship and the relation between the civic body and those who are left out of it. Therefore, in the following pages we will look at how these theoretical concepts are linked to the understanding of the phenomenon of the erasure. 


\subsection{Human rights}

Particularly interesting is the relation between the erased and the concept and practices of human rights. One assumes that human rights are the basic rights ascribed to a person by his birth, and it is thus practically impossible to lose them during a lifetime. The case of the erased proves that kind of thinking wrong. It is true that the erased (largely) did not lose their lives, as was the case for numerous people during the wars in the Balkans, but they did still lose their human rights, despite being alive. As shown next, that was possible because of the immanent connection between human and citizen rights.

In principle, human rights belong to all individuals with their birth, but they can be granted only by sovereign national states, this resulting in citizenship being the basis for accessing human rights. No other institution exists outside of the state that would ensure the individual's fundamental rights. Therefore, the prevention of statelessness is one of the main principles in international law. The states are obliged to follow it when determining their civic body, since it is difficult to ensure human rights to those who find themselves without any kind of citizenship or permanent resident status. Their rights are easily violated, since there is no body or institution that would provide them. National states are thus the sole political units that can provide the only space where human rights can be exercised (Arendt, 1979).

The problem of those who lost their human rights or whose rights were violated is that they lost a place where they would be heard, where their opinion would be relevant and public. The most significant aspect of the loss of human rights is the loss of possibilities to be seen and heard, in the words of Hannah Arendt, "the deprivation of a place in the world which makes opinions significant and actions effective" (1979: 296). Individuals thus cease to be politically relevant creatures, they are left to be only humans, without any right to act or have an opinion. Therefore for Arendt, the person without citizenship or permanent resident status is the human rights person par excellence, because such an individual is entitled to those rights only, and not citizen or permanent resident rights. She states that "[w]e became aware of the existence of a right to have rights (and that means to live in a framework where one is judged by one's actions and opinions) and a right to belong to some kind of organized community, only when millions of people emerged who had lost and could not regain these rights because of the new global political situation" (Arendt, 1979: 296-297).

The national state is therefore essential to ensuring legal and political equality and, thus, the protection of all rights. The states should establish a 
legal system that protects the rights of everyone, regardless of the different nationalities, but instead the nation has often been privileged over the state, which causes a nation to dissolve into an anarchic multitude of privileged and underprivileged individuals. That was fatal for the minorities, for nonmembers of the nation and for those who were left without any country. Statelessness or the loss of the citizenship became the basis of total loss of all rights (Jalušič, 2007). In the case of the erased, the non-acquirement of Slovene citizenship resulted in complete loss of human rights, since there was no state granting these rights to individuals. The erased were left with citizenship of a state in disintegration and without citizenship of the newly emerged state, thus, de facto, becoming stateless persons.

In her book exploring universal human rights and the idea of selfdetermination, Seyla Benhabib writes that " $[t]$ he right to have rights can be realized only in a political community in which we are judged not through the characteristics which define us at birth, but through our actions and opinions, by what we do and say and think" (Benhabib, 2004: 59).

Defining the civic body of the state, on the one hand, has always meant mass exclusion on the other. This way, modern nations have established territorially bounded national sovereignty, achieving internal homogeneity through dialectical definition of Others, who were excluded, dehumanised and left without any rights. Establishment of imperial sovereignty thus implies the mutual normalisation and integration of exclusionary practices (Kurnik, 2007).

The newly formed Slovene civic body, which was defined by ethnic measures at the time of the creation of the independent state, left out those individuals who were not perceived as ethnically Slovene. This had a great impact on the group of the erased, since they were left outside the state's protection. Wars in the other Yugoslav republics forced some of them to return to their ethnic origins, while others were ethnically Slovenian but victims of administrative procedures as well. They were perceived as nationals of some other state (Yugoslavia) that was in the process of disintegration and they did not posses any other nationality, therefore becoming stateless persons. They were thus completely excluded from society. It took a decade for them to be able to recognise their common position, to gain a voice in public and claim their own rights.

Since such exclusive principles are often connected to nationalistic doctrine, we take a short closer look here into the theories of nationalism. Nationalism in its exclusive understanding was a crucial basis for the erasure to be possible, since the new state was perceived as the property of the Slovene nation, ensuring the hegemonic position of the majority ethnic group. 


\subsection{Nationalism}

Nationalism has a relatively ambivalent nature; it can be characterised as a political movement willing to achieve protection of collective cultural and political rights, autonomy or self-determination, state ideology, or (most often) as an extreme emotion of hatred against foreigners, cultural exclusivism and xenophobia. Reasons for such plurality of perception lie in the inability of scholars of nationalism to distinguish between the two dimensions of nationalism. On one hand we have "traditional" nationalism that argues for a state/country for every nation; the nation-state has to belong to its ethno-cultural or political group to protect its interests (culture, traditions, heritage and territory) and enable it to flourish. This form of nationalism is perceived as "classic nationalism" that most thrived in $19^{\text {th }}$ century Europe and later spread around the world like an epidemic, even today marking some contemporary nationalisms. That was the case of Slovene nationalism in the 1990s, when the state formation was based on the nation-state perception, the newly formed state being perceived as the protector of the majority ethnic group, i.e. the Slovenes. Smith (2001: 12) clearly states that nation is not a state, because the concept of a state refers to an institutional, structural activity, while the nation indicates the type of community. Similarly, according to Smith, the nation is not an ethnic community (although they partly overlap, being members of the same family of phenomena, e.g. collective cultural identities) because "the ethnic community usually has no political referent, and in many cases lacks a public culture and even a territorial dimension, since it is not necessary for an ethnic community to be in physical possession of its historic territory" (Smith, 2001: 12).

There are strong debates among scholars about when the nation and nationalism emerged in human history. Are they truly ancient phenomena as primordialists claim or something completely new, potentially associated with industrialisation, standardisation of language, mass literacy, or maybe a political consequence of the American and French revolutions as modernists believe. Another theoretical position, ethno-symbolism, offered by Anthony D. Smith, as the internal critic of modernism, claims that nationalism and the nation-state are phenomena of modernity, but that we can identify some pre-existing criteria (traditions, myths, and another ethno-symbolic attributes that existed before the emergence of modern nation-state). At first glance, this unsolvable situation can be demonstrated by Gellner's stressing that "nationalism is not the awakening of nations to self-consciousness: it invents nations where they do not exist" (1964: 169), and Smith's response that "nations and nationalism are no more 'invented' than other kinds of culture, social organization or ideology" (1991: 71). 
In a similar way, Smith rejects some other conceptions of nationalism, for instance, the claim that nationalism is "by nature" an extreme force. Smith says that this is true to some degree, but we also know some rather moderate and democratic nationalism (Czech, Catalan, Quebecois) demonstrating that generalisation is not appropriate. In many cases this is true, but there are other nationalist movements that address their appeal to collective, cultural and minority human rights. Many see nationalism as the key source of destabilisation, and such argument is seen by nationalism as a destructive and destabilising factor. Again, in most cases this is true, but nationalism is not responsible per se for the collapse of states; nationalism usually develops on the ruins of existing states (Smith, 1995: 152). The destructive power of nationalism is the other side of the coin, as the first side is uniting - depending on the reference frame. Smith says that modern nationalisms have become what religious communities used to be in the past (nationalism as secularised religion), "communities of history and destiny that confer on mortals a sense of immortality through the judgement of posterity, rather than through divine judgement in an afterlife" (Smith, 1995: 158-159). In this regard also, Slovene nationalism played the same dual role - on the one hand, it was used to homogenise the nation and played an important role in the strengthening of national identity, but, on the other, it was used to made a division between "true members" and others, especially other Yugoslav nationals.

As mentioned above, most people connect the idea of nationalism to ethnocentrism and racism, and violence and hatred against outside groups (Lichtenberg, 1997: 158). In their opinion, nationalism is an evil we must overcome and replace with cosmopolitanism. On the other hand, the idea on nationalism offers some positive connotations like attachment to democracy, community, autonomy, aspiring for freedom and preservation of cultures, languages and traditions. Regardless of its ratings, one can solidly claim that nationalism is (still) powerful, it is addressing the masses and responding to the aspirations of many communities. Doing this, nationalism is greatly supported by (rational) arguments, usually referring to a) the right to self-determination (the self-determination argument), b) the right to prosperity, arguing that every man needs to identify with some broader community, bigger than his or her family (the prosperity argument), c) the right to redress those collective injustices that were committed in the past (the reparation argument), d) the view that the world is a better place if it possesses diverse cultures (the plurality argument), and e) the view claiming that the existence of a distinctive culture requires its preservation and its flourishing, that every culture has its specific value, so it is legitimate 
to preserve it (the inner value argument) (Lichtenberg, 1997: 160-161). Although the author is resisting the arguments of nationalism, she is not successful in her mission since she is not offering any alternative to the nationalist(ic) imagining of the world. She notes that every culture will not reach the final stage of self-determination, the independent state, yet it is, however, possible to use different policies of multiculturalism in multicultural communities (promotion of minority languages and other cultural practices) to achieve peaceful co-existence. In this sense, only multiculturalism is the answer, and the politics of recognition that takes from nationalism what is acceptable and directs it to more cosmopolitan ways (Lichtenberg, 1997: 172).

For some years, Slovene nationalism was perceived mainly in the positive perspective, especially in regard to nationalisms in other former Yugoslav republics that lead into devastating wars, which was not the case in Slovenia. Still, the phenomenon of the erasure reveals the other side of Slovene nationalism, which was exclusive and hostile to the perceived nonmembers. Therefore, we argue that further studies of Slovene nationalism should always take into account the erasure as the other side of the coin of the disintegration and state-building processes in the 1990s.

The legal consequences of the erasure were directly linked to the lack of citizenship status, which was the basis for deprivation of political, economic and social rights. The erased thus form part of those de facto stateless persons who open up many dilemmas about nationality, nationalism and citizenship. Due to numerous questions that remain unanswered when granting citizenship, and when including and excluding from the civic bodies of national states, and various discriminatory practices brought about by the modern conception of citizenship, thoughts about a broader notion of citizenship emerged, considering new opportunities that broader, transnational or global citizenship might open for today's excluded individuals.

\subsection{Forms of citizenship}

Some languages distinguish citizenship from nationality, where citizenship stands for "legal relationship, regulating the totality of mutual rights and duties that may exist between an individual and a state" (Horn, 1998, cited in Dedić, 2003: 25-26), and is referred to domestic legal order. According to Dedić (2003: 26), nationality stands for "the legal relationship between an individual and a state in international law", a state thus granting diplomatic protection to its nationals. In languages that use only the term nationality, it often contains a notion of ethnic affiliation, which is common in Central and Eastern Europe. However, as Dedić observes, the European 
Convention on Nationality perceives nationality as "the legal relationship between an individual and a state, not reflecting ethnic origin of the individual" (Dedić, 2003: 26).

As explained above, national citizenship as a paradigm for interpretation of the relationship between the citizen and the individual non-citizen in the political community envisages that citizen rights overlap human rights. In Europe, the possibility to overcome national citizenship system is brought forward by the introduction of European citizenship, whose body is difficult to determine, since that depends on the way in which Europe and European Union are defined. In addition, the Maastricht Treaty of 1992 defined the EU citizen as every individual holding the nationality of a Member State. EU citizenship thus complements national citizenship and does not replace it. Therefore, the legal function of national citizenship remained unchanged. Currently, a European citizen is anyone who has the nationality of a Member State. This way, instead of exceeding the limits of national citizenship, the European Union has created a new discrimination (Rethinking European Citizenship, 2003; Tuccillo Castaldo, 2007; Balibar, 2004).

Despite the idea of Europe overcoming the dividing line between sovereign national states, it seems that the European Union as a political entity has included both elements: the nation and the state. Thus, by not overcoming national citizenship systems and expanding the "right of residency" (ius soli), which would enable real citizenship on the basis of residing in Europe, the European Union has created a new discrimination. Third country immigrants are now discriminated not only by national states, in which they settle, but also by the European Union. Immigrants are radically discerned to be those from other member countries and those from countries outside the EU, the so-called "third" countries (Balibar, 2004). Tuccillo Castaldo (2007) argues that the EU enlargement includes several levels of exclusion. The EU's external borders are expanding largely with the aim to monitor migration flows, while supervision over inferiorised populations is becoming harsher within the EU. Moreover, citizenship legislation is evolving in a way that naturalisation processes are increasingly determined by economic-income criteria and, at the same time, the ius sanguinis principle is becoming more and more relevant. Foreigners have become secondclass citizens (Balibar, 2004: 171), who are often stigmatised, their stay and activity being strictly controlled. The European citizenship that would be granted to the erased on the basis of their residence in the European Union (after Slovenia's accession) would provide them with legal status and their human rights. But since European citizenship functions only as the exten- 
sion of existing citizenships, the erased could not become European citizens without Slovene citizenship, thus being discriminated again.

Citizenship is to be understood in the broader social context, not only as a legal category. Balibar (1988: 724) understands citizenship in a narrow sense as "full exercise of political rights" and in a broader sense as "cultural initiative or effective presence in the public space (the capacity to be 'listened to' there)". These two tendencies, to equate citizenship to nationality on the one hand, and to consider citizenship solely as legal fiction on the other, were differently balanced throughout history. But Balibar warns that the dynamic relation between the citizen and the state is overlooked in both cases and therefore talks about "worksites of citizenship" (2004: 198), thus exposing the dynamic link between the state and the individual. Balibar argues that it is necessary to find a new type of citizenship that will overcome its bonds today to a national state. Citizenship is namely a process, formed by those who invoke the right to be citizens. In addition, the citizenship we know today was created through historical battles and struggles that will also be needed in the future. As an alternative to today's citizenship, Balibar introduces the term droit de cité (the right to citizen rights), which facilitates the distinction between formal citizenship and citizenship practices, and represents firm liberalisation of the right of residence and work. At the same time, it grants inclusiveness and expansiveness of citizenship as collective emancipation, thus representing a kind of driving force, which opens and broadens the boundaries of existing citizenship institutions. Citizenship is not only given from above but is largely constituted from below, which empowers active citizenship. Therefore, the project of opening borders is based on the basic participation of those who invoke droit de cité, even though they are not formally citizens of a particular nation-state (Balibar, 2004).

Modern citizenship contains two important deviations from the principles of universality, inclusiveness and democracy. The first deviation is the distinction between passive and active citizenship, respectively between congenital equal and inalienable rights on the one hand, and participation in decision-making on modalities of their implementation on the other. The second deviation is the relation between rights and nationality by birth. Therefore, the arrival of a foreigner or a refugee suspends the image of the national state as the one capable of granting human and citizen rights (Kurnik, 2007).

Global citizenship is another alternative to national state citizenship. It is even vaguer than European citizenship, since global citizens (in contrast to the European citizens as one of the post/trans-national categories) are not 
a legal category, and one can only imagine their existence and functioning as a kind of informal association of like-minded persons. Because there is no such thing as a global bureaucracy or a global government that would protect global citizens, they can simply live and work within transnational frames, denying and avoiding national borders and national sovereignty. Steenbergen proposes more than just a technical definition of a global citizen as he describes him in more holistic terms: individuals get to choose where they work and live and are no longer attached to (their) state or location where they were born (Steenbergen, 1994: 138). In the age when power was in the hands of ethnic and exclusivist models of nationalism, the political discourse of global citizenship was nevertheless on the rise (Carter, 1997).

The concept of global citizenship, originating in cosmopolitan values, is based on early Western thought and was articulated during the Enlightenment. Interests in this concept have recently risen, since the world is facing increasing global integration, environmental interdependence and the information revolution. International organisations (mostly non-governmental) have achieved that individuals share a greater responsibility for tragedies, wars, pollution and other global problems, even when they do not happen in the immediate vicinity, but on the other side of the world. The debate on global citizenship is at the same time an extension of the renewed debate about the role and power of citizenship within the state. In the eyes of many, the two concepts (global and national citizenship) exclude one another, because they supposedly address and defend contradicting positions (the former - universal values and moral duties towards the whole humanity, and the latter - values and duties towards a specific community, culture or state). From the perspective of nationalism and the nation-state, cosmopolitanism seems to be shallow, since it lacks rooting in a specific and identifiable community. According to nationalism, cosmopolitanism addresses too abstract and unreal universalistic requirements for duties. On the other hand, the cosmopolitan view perceives nationalism as narrow-minded, exclusive, xenophobic and intolerant towards the rights of all who do not fall under the umbrella term of a national community (Carter, 1997).

Although it seems at the first glance that there is a conflict between nationalism and global citizenship, the conflict between political affiliation to a specific country and the ideals of global citizenship is in fact not necessary. Neither does the pride of a specific culture and identity exclude more universal feelings of global belonging. As Carter says (1997), it is possible to find some forms of nationalism that are compatible with the original cosmopolitanism, especially for those who express commitment to 
universalistic political principles, namely liberalism and republicanism and who accept responsibility beyond national borders.

Despite that fact, that there are concepts and hopes to form a post-national citizenship that would be based solely on human rights, the national states remaining the only entities that only provide space, where human rights can be not only exercised but also advocated for all the excluded. Given that the realisation of human rights in everyday life often coincides with citizenship status and a residence permit, it is of vital importance to defend the right to citizenship.

How is the above discussion on citizenship relevant to our case? In Slovenia, the case of the erasure showed the importance of citizenship status, since many of the erased became de facto stateless persons. National citizenship was not granted to the erased, since they were not perceived as being a part of the newly formed state. With the entry of Slovenia into the European Union, there were some hopes that European citizenship might be granted to all residents of the Union. But since European citizenship was only an addition to the national one, joining to the European Union meant another exclusion for the erased, since they were deprived of two citizenships from then on. A wider notion of citizenship - national, European or global - that would be based on the individual's residence or activity or other citizenship practices, would significantly contribute to solving the problem of stateless persons.

\section{What about Europeanisation?}

Key question that the researchers of modern Slovene political history have been trying to answer for the last twenty years is about detecting the aspirations that have led the Slovene independence movement. The dilemma is the following: firstly, was the independent state only a means for the democratisation that was not possible within the frame of Yugoslavia, or was the democratisation an "excuse" to gain independence? And secondly, was the formation of the independent state a consequence of the wish to join the European Union, as democratisation was the necessary condition to achieve this goal, or was democratisation the elementary wish and goal that would automatically lead to Europeanisation?

The posed questions can be answered by strictly following the process of the disintegration of Yugoslavia and the decisions of the Slovene political (and also cultural and intellectual) elites, who led the process of the Slovene independence. We could argue that in the late 1980s, the Yugoslav republic of Slovenia truly wished for the democratisation of Yugoslavia. When accepting the ignorance of such aspirations among the Yugoslav leadership, it took 
the following steps (free elections, new democratic legislation, etc.) that led to the formation of the independent state of Slovenia. However, at the crucial moment of the independence process we can observe a rupture between forces that were focusing on the independence and the state-building processes, and forces whose primary goal was democratisation. What both had in common was the aspiration to join the European community at the shortest possible notice, since it represented a promise of economical development and a guardian of fundamental democratic standards. Therefore, Europeanisation was once again, similarly to the process of independence, seen as a selfevident transition to a presumably higher level of democracy. The adherence to the European Union meant a final confirmation of Slovenia's European identity and its most visible distinction from other former Yugoslav states. That became even more obvious with the accession to the Schengen space, when, according to Vidmar Horvat, a new era of negotiations on European identity and the identity of Europe began. Schengen Europe caused a redefinition of the hierarchies of inclusion and exclusion (Vidmar Horvat, 2009). Slovenia found itself on the "right" side, but the erased were once again "left out of democracy". The independence of Slovenia led them to a stateless position and the Europeanisation brought them even further exclusions.

This immanent anti-democratic link between independence and Europeanisation is even more traumatic considering how Europeanisation was perceived among the erased as a process that would finally end the injustices caused by the Slovenian state, but the reality did not bring any direct solution. In the European Union, the erasure was not perceived as an obstacle for the accession of Slovenia. As Shaw states in her study about citizen regimes in South Eastern Europe, EU institutions did not utilise Slovenia's pre-accession process in order to force progress in relation to the erasure, even though it has been characterised as a serious human rights violation by organizations such as Amnesty International and the Commissioner for Human Rights at the Council of Europe (Shaw, 2010). The erased, who did not possess Slovene citizenship, were not granted European citizenship, thus remaining stateless. Nevertheless, the erased have spread awareness of the problem to some European institutions, thus taking advantage of the new source of political pressure on the Slovenian authorities. They succeeded with their law suit before the European Court of Human Rights, which is obliging Slovenia to grant the erased their human rights. Following (or not) the judgment of the court, it will be the indicator of the democratisation and Europeanisation of Slovenia in the near future, and a test for the European Union to overcome its double standards when defending human rights. Since "the rather hidden fate of the Erased failed to make 
a substantial dent in the overall success rate of Slovenia, which has been widely seen in international spheres as the only success story of the dissolution of Yugoslavia and a deserving member of the '2004 team' - i.e. the first post-1989 enlargement of the EU towards Central and Eastern Europe" (Shaw, 2010: 22), the acceptance of the European Court's decision will put Slovenia's democratic standards and European values to the test.

Many studies of new democracies claim that the international context may influence transitions (toward democracy). As Rizman puts it, "the Eastern and Central European countries had never before known more favorable conditions for change and, in terms of democratic consolidation, had never seen a combination of international factors more conductive to that process" (Rizman, 2006: 151). However, we might argue that this international influence did not successfully influence Slovenia when it was dealing with the erased (prior to and after becoming a member of the EU and other international organizations) to redress fully the injustices that took place almost twenty years ago.

\section{Conclusion}

The process of disintegration of the federal state and the re-nationalisation of Slovenia as an independent state, presented a state-building process that was much more peaceful than similar processes in other former Yugoslav republics. Nevertheless, the emergence of (ethnic) nationalism inflicted some large gaps in Slovene democracy, the biggest among them being the act of the erasure. To explain this phenomenon and to place it into the socio-historical context, we cannot avoid the theoretical reflection of the key concepts that characterise state-building - namely nationalism, human rights, and the theory and practice of citizenship. With the attempt to shed light on certain theoretical factors in the studies of citizenship, nationalism and human rights we seek for the details to explain the circumstances of the erasure and to place it into a broader theoretical frame as a key example of the contemporary dilemmas in theoretical research. The process of democratisation in Slovenia was widely seen as the only success story of the dissolution of Yugoslavia, and its accession to the European Union in 2004 was perceived as a well deserved reward.

In the process of state-building, the ethnonationalist approach in conceptions of citizenship was applied. Instead of models of multiculturalism and cosmopolitanism as the moral imperatives of the European Community, the most desired destination of a newly independent state, the creation of independent Slovenia was based on the ethnic model of (re)nationalisation. With the protection of "indigenous", "autochthonous", "historic" minorities, 
Slovenia met the political criteria (and the desire to prove its democratic orientation to the international community), while completely ignoring the so-called new minorities that had emerged in decades of living in the common Yugoslav state.

Moreover, the erased were not only not granted minority rights, their legal status was completely denied. As a result of not obtaining Slovene citizenship, they were deprived of their permanent resident status, which caused a complete loss of their rights. They became stateless persons, without any of the rights that are granted by the nation states. As we have explained, they lost their basic "right to have rights", causing their total disappearance from the public sphere. As the phenomenon of the erasure shows, the current national citizenship is not an appropriate model for granting individual rights. As we have pointed out, citizenship should therefore evolve, taking the form of a European or even a global category.

Europeanisation is the process that is most vital today. To join the European Union, Slovenia had to meet some requirements, also concerning the state of democracy. However, the issue of the erased was overlooked in the process of Europeanisation of Slovenia. The European Union did not use the pre-accession process to force Slovenia to solve the question of the erased. Thus, for the erased, both democratisation and Europeanisation were therefore only "empty words", leaving them without any political protection. The erasure being the main hole in Slovenian perforated democracy, it can serve as an indicator - in theoretical terms - of the ambiguities and contingencies that define the outcome of the processes of Slovenian democratisation and Europeanisation.

\section{REFERENCES}

Aliens Act [Slovenia], Official Gazette of the Republic of Slovenia, No. 61, 30 July 1999, http://www.unhcr.org/refworld/docid/3ae6b59c14.html (03.01.2010).

Alvis, Robert E. (2005). Religion and the Rise of Nationalism: A Profile of an East-Central European City. Syracuse: Syracuse University Press.

Anderson, Benedict (1995). Imagined Communities: Reflections on the Origin and Spread of Nationalism. London: Verso.

Arendt, Hannah (1979). The Origins of Totalitarianism. New York: Harcourt Brace and Co.

Balibar, Étienne (1988). "Propositions on Citizenship", Ethics, 98 (4): 723-730.

Balibar, Étienne (2004). We, the People of Europe? Reflections on Transnational Citizenship. Princeton: Princeton University Press.

Bebler, Anton (2010). "The dissolution of the Yugoslav federation: its causes and consequences", Europejski prezeglad prawa i stosunków międzynarodowych, no. 1: $31-52$. 
Benhabib, Seyla (2004). The Rights of Others: Aliens, Residents, and Citizens. Cambridge: Cambridge University Press. doi:10.1017/CBO9780511790799

Carter, April (1997). "Nationalism and Global Citizenship", Australian Journal of Politics \& History, 43 (1): 67-81. doi:10.1111/j.1467-8497.1997.tb01379.x

Connor, Walker (1994). Ethnonationalism: The Quest for Understanding. Princeton: Princeton University Press.

Conversi, Daniele (2003). "Conceptualizing nationalism: An introduction to Walker Connor's work", in: Daniele Conversi (ed.). Ethnonationalism in the Contemporary World: Walker Connor and the study of nationalism. London: Routledge, pp. 1-23.

Dedić, Jasminka (2003). "Diskriminacija v postopkih pridobivanja slovenskega državljanstva", in: Jasminka Dedić, Vlasta Jalušič and Jelka Zorn. Izbrisani: organizirana nedolžnost in politike izključevanja. Ljubljana: Mirovni inštitut, Inštitut za sodobne družbene in politične študije, pp. 23-84.

Fink-Hafner, Danica (1995). "The Disintegration of Yugoslavia”, Canadian Slavonic Papers, 37 (3-4): 339-356.

Gellner, Ernest (1964). Thought and Change. London: Weidenfeld and Nicholson.

Gellner, Ernest (1983). Nations and Nationalism. Ithaca: Cornell University Press.

Glenny, Misha (1996). The Fall of Yugoslavia: The Third Balkan War. London: Penguin Books.

Glover, Jonathan (1997). "Nations, Identity, and Conflict", in: Robert McKim and Jeff McMahan (eds). The Morality of Nationalism. Oxford: Oxford University Press, pp. 11-30.

Izbrisani: pravna in moralna dolžnost Slovenije (2010). Ministry of the Interior, http://www.mnz.gov.si/si/teme_in_programi/izbrisani_pravna_in_moralna_ dolznost_slovenije/\#c17609 (28.03.2010).

Jalušič, Vlasta (2003). "Organizirana nedolžnost”, in: Jasminka Dedić, Vlasta Jalušič and Jelka Zorn. Izbrisani: organizirana nedolžnost in politike izključevanja. Ljubljana: Mirovni inštitut, Inštitut za sodobne družbene in politične študije, pp. 7-22.

Jalušič, Vlasta (2007). "Organizirana nedolžnost in izključevanje: nacionalne države in državljanstvo po vojni in kolektivnih zločinih", Časopis za kritiko znanosti, 35 (228): 101-121.

Janjić, Dušan (1992). "Disintegration of Yugoslavia and inter-ethnic conflicts", International Scientific Conference Nation and State - Small Nations and Ethnic Minorities in an Emerging Europe, Maribor, Slovenia, 3-5 February 1992.

Kogovšek, Neža (2007). "Izbrisani: predlog ustavnega zakona kot negacija pravne države", Časopis za kritiko znanosti, 35 (228): 177-193.

Kralj, Ana (2009). When Ć becomes $\check{C}$ : discrimination of unrecognized national minorities in Slovenia. Ljubljana: University of Primorska, Science and Research Institute.

Kurnik, Andrej (2007). “Izbrisani gredo v nebesa”, Časopis za kritiko znanosti, 35 (228): 122-131. 
Kymlicka, Will (2007). Multicultural Odysseys: Navigating the New International Politics of Diversity. Oxford: Oxford University Press.

Lichtenberg, Judith (1997). "Nationalism, For and (Mainly) Against", in: Robert McKim and Jeff McMahan (eds). The Morality of Nationalism. Oxford: Oxford University Press, pp. 158-175.

Lipovec Čebron, Uršula (2007). "Metastaze izbrisa”, Časopis za kritiko znanosti, 35 (228): 59-75.

Lockard, Craig A. (2008). Societies, Networks, and Transitions: A Global History. Boston: Houghton Mifflin Company.

Matić, Davorka (2006). "Je li nacionalizam stvarno toliko loš: slučaj Hrvatske", in: Sabrina Ramet and Davorka Matić (eds). Demokratska tranzicija u Hrvatskoj: transformacija vrijednosti, obrazovanje, mediji. Zagreb: Alinea, pp. 261-284.

Petrović, Tanja (2009). A Long Way Home: Representations of the Western Balkans in Political and Media Discourses. Ljubljana: Peace Institute.

Ramet, Sabrina (1996). Balkan Babel: The Disintegration of Yugoslavia from the Death of Tito to Ethnic War. $2^{\text {nd }}$ edition. Boulder: Westview Press.

Report on Roma Community in the Republic of Slovenia. http://www.uvn.gov.si/ en/minorities/roma_community (22.03.2010).

Rethinking European Citizenship (2003). http://www.ezd.si/fileadmin/doc/4_AKTIVNO_DRZAVLJANSTVO/Viri/Rethinking_European_citizenship_ecas.pdf (21.03.2010).

Rizman, Rudi (2006). Uncertain Path: Democratic Transition and Consolidation in Slovenia. College Station: Texas A\&M University Press.

Shaw, Jo (2010). "The constitutional mosaic across the boundaries of the European Union: citizenship regimes in the new states of South Eastern Europe" (University of Edinburgh, CITSEE Working Paper 2010/07), http://www.law.ed.ac. uk/publications/workingpapers.aspx.

Smith, Anthony D. (1981). The Ethnic Revival. Cambridge: Cambridge University Press.

Smith, Anthony D. (1991). National Identity. London: Penguin.

Smith, Anthony D. (1995). Nations and Nationalism in a Global Era. Cambridge: Polity Press.

Smith, Anthony D. (2001). Nationalism: Theory, Ideology, History. Cambridge: Polity Press.

Steenbergen, Bart van (1994). "The Condition of Citizenship", in: Bart van Steenbergen (ed.). The Condition of Citizenship. London: Sage Publication, pp. $1-9$.

Tuccillo Castaldo, Imma (2007). "Imobilizirana državljanstva”, Časopis za kritiko znanosti, 35 (228): 139-147.

Vidmar Horvat, Ksenija (2009). Zemljevidi vmesnosti: eseji o evropski kulturi in identiteti po koncu hladne vojne. Ljubljana: Sophia 


\title{
Perforirana demokracija: dezintegracija, izgradnja države, europeizacija i izbrisani Slovenije
}

\author{
Damjan MANDELC, Tjaša UČAKAR \\ Odsjek za sociologiju Filozofskog fakulteta Sveučilišta u Ljubljani, Slovenija \\ damjan.mandelc@guest.arnes.si,tjasa_ucakar@yahoo.co.uk
}

\begin{abstract}
U radu se istražuje procese dezintegracije Jugoslavije, proces izgradnje države u Sloveniji i kontekst specifičnoga fenomena - brisanja, koji se zbio u Sloveniji ranih devedesetih godina 20. stoljeća. Rekonstruiraju se društveno-povijesni i politički konteksti, u kojima je došlo do neovisnosti Slovenije. Opisivanjem procesa izgradnje države, procesa demokratizacije i dvojbi glede zaštite manjina u Sloveniji - uključujući razliku između priznatih »autohtonih« i nepriznatih »novih" manjina - utire se put teorijskoj i sociološkoj raspravi o »izbrisanima«. Teorijska rasprava temelji se na pitanjima ljudskih prava, nacionalizma i građanstva, kako u njihovoj klasičnoj (nacionalnodržavnoj) koncepciji tako i u njihovim alternativnim oblicima poput globalnoga građanstva. Sociološki, rasprava »brisanje« smiješta u širi okvir istraživanja procesa demokratizacije i europeizacije, osvetljujući tako ključne čimbenike koji su prouzročili perforiranu demokraciju u Sloveniji tijekom dvadeset godina njezine neovisnosti.
\end{abstract}

Ključne riječi: dezintegracija države, izgradnja države, europeizacija, izbrisani Slovenije, demokratizacija, ljudska prava, građanstvo (građanski status) 